\title{
DE-ICING OF AIRCRAFT: INCORPORATING BUSINESS RISKS AND OCCUPATIONAL HEALTH AND SAFETY
}

\author{
S. NADEAU \& FRANÇOIS MORENCY \\ Mechanical engineering, École de technologie supérieure, Canada.
}

\begin{abstract}
Airliner maintenance is a high-risk sector from an occupational health and safety perspective. In the current context of increasing air traffic worldwide and in view of the economic and safety issues associated with aircraft maintenance, it is imperative that companies providing this service receive support in their quest to reconcile operational performance with OHS. A survey of interdisciplinary research published from 2004 to 2014 allowed analysis of current thought in industrial engineering, human factors engineering and aeronautical de-icing, thus revealing a need for the design of aircraft de-icing activities that are sustainable, holistic and integrated. In response to market evolution, aeronautics will have to offer aircrafts that are greener, meaning safe for all users (including maintenance workers) and the environment throughout the product lifecycle.

Keywords: aeronautics, aircraft maintenance, aviation, de-icing, human factor engineering, integrated risk management, occupational health and safety, sustainable development
\end{abstract}

\section{INTRODUCTION}

The aim of sustainable development is to meet present needs of populations throughout the world without compromising the capacity of future generations to do so. In view of this, the International Labour Office (ILO) upholds the right of employees to work under conditions that do not threaten wellbeing, meaning that adequate measures are in place to prevent accidents and occupational illnesses. Whether in construction, manufacturing or other sectors, several researchers have concluded that achieving true sustainability will require an approach that is more holistic than that being taken in most cases (Hinze et al. [1], Haslam \& Waterson [2], Demirel \& Duffy [3], Lozano \& Huisingh [4]). This means more precisely that pro-active preservation of all resources including human capital throughout the lifecycle of an economic activity, be it mining, air transport or other, is now a pre-requisite for future development (Dul et al. [5]).

The aviation sector foresees a major increase in future air traffic: 5-10\% per year, depending on the continent (OACI [6]). Boeing estimates that 36,000 passenger aircraft will be in service in 2025 (Boeing [7]). One hour of flight requires 12 hours of aircraft maintenance (Rashid et al. [8]). A quadratic relationship exists between air traffic volume and accident rate, which explains the recommendations to increase safety levels by a factor of three by 2020 and by ten on the long term if air traffic should triple (Vogt et al. [9]). According to airliner incident and accident reports, the principal cause is improperly completed procedure (Drury and Johnson [10]), information corroborated by an Australian study (Hampson et al., 2012 [88]). Maintenance activities represent 10-15\% of airline budgets, two thirds of which are for labor costs in the case of heavy maintenance burdens (McFadden and Worrells 2012 [11]). In the case of commercial flight, the proportion of accidents related to airliner maintenance is $12-20 \%$ (Rashid et al. [8]). In Europe, 10-20\% of workplace accidents and 10-15\% of deaths in all industrial sectors are associated with maintenance activities (EU-OSHA [12]). In 2002, there were no fatalities in the Québec air transport maintenance sector, although numerous accidents and occupational illnesses were reported, leading the province's occupational health and safety commission to rate this sector as high risk. 
The literature is replete with studies describing the associations between deficient measures for accident or occupational illness prevention and drops in productivity, losses of business competitive advantage and even drops in national economic growth and competitiveness (HESAPRO [13]) and individual and corporate social wealth (Dul et al. [5]). Furthermore, organizational innovation through rapid and flexible adoption of innovative approaches to the design and management of production systems appears to favor sustainable business models (HESAPRO [13]). Market globalization, technological change and business regulation is leading to profound, rapid and continuous changes in corporations, notably in the workplace (Kristensen [14]). Production systems are becoming more integrated and complex, characterized by greater process interdependence, greater numbers of variables and arbitrations to be managed (Costella et al. [15]), focus on high-value-added products, and design based on cutting-edge technologies and knowledge. A sustainable business must place increased emphasis on balancing its performance imperatives with the wellbeing of its workers (Westgaard and Winkel [16]). We examine the question of how this might be achieved in the airliner maintenance sector, and more specifically in the context of de-icing operations, based on the available literature on integrated risk management, on maintenance operations and on ground de-icing. We analyze this knowledge from the perspective of justifying the need for modeling as means of developing sustainable and holistic de-icing activities that will ultimately balance worker performance with worker wellbeing. Further researches should be conducted to develop technology to reduce human-factor associated variability in de-icing activities. The models could help improve the integration of ergonomics in the de-icing procedure, through the development of task specific documentation and training. Tools to integrate variability into the risk evaluations of critical task are also needed and could eventually lead to design improvements at the aircraft level.

\section{AERONAUTICAL DE-ICING}

Icing of aircraft surfaces cannot be avoided completely and remains a significant cause of accidents. It can occur during flight or on the ground, whenever the aircraft encounters frosting conditions. Accumulation of ice on the wings of an aircraft increases the stalling speed and modifies the flight envelope, which may lead to accidents (Brown [17]). Certification authorities therefore define an envelope of the most probable icing conditions, and aircraft manufacturers must demonstrate that their planes fly safely under these conditions. For an aircraft to obtain authorization for flight through icing conditions, the manufacturer must install anti-icing systems, which are often based on heating of the wings (Hannat and Morency, [18]). When icing conditions arise on the ground before takeoff, the aircraft must be de-iced and protected against subsequent frost deposition using de-icing liquids.

Aircraft de-icing shares most of the common maintenance problems related to deregulation in the aircraft industry. In Canada and USA, the air carrier must have a ground de-icing program approved by the authorities, but outsourcing of aircraft ground de-icing services is becoming the norm (FAA, [92]). Although new policies have been under development over the last 10 years, no procedure yet exists for the service provider to have an approved de-icing program, as in some other aircraft maintenance activities. The service provider has to comply with every air carrier de-icing program, as many as 25 different air carriers (EASA, [94]). Another particularity is the fact that offshore de-icing activities are inevitable, as de-icing must be done at the aircraft departure airport if icing conditions occur. Contrary to most maintenance activities (Quinlan, 2013 [91]), human errors in de-icing have immediate effects, either by exposing workers to injury or by jeopardizing aircraft takeoff. Most airports nowadays have a single service provider dedicated to de-icing activities, potentially resulting in a 
growing level of experience and higher level of service (EASA, [94]). The typical centralized service provider is well organized with good training, experienced supervisors and management systems, avoiding some previously identified failures in other aircraft maintenance activities (Quinlan, 2014 [90]). The typical employee, however, has been with the company for less than 2 years, almost always does part time and seasonal work, and often it is his/her first exposure to aircraft maintenance work (EASA, [94]).

When conducting de-icing tasks on aircraft, maintainers are exposed to many risks as falls from heights of ten meters or more, splashes or run-offs of fluids from the aircrafts, the platform colliding with the aircraft, being sucked towards the intake of running motors during audit of small aircraft, slipping on the ground during audit of small aircraft, direct exposure to de-icing/anti-icing fluids, direct exposure to conditions on the airport tarmac (cold temperature, wind-chill factor, noise, glare (passing from darkness to brightness), musculoskeletal lesions associated with working postures and the weight (about 3 to $5 \mathrm{~kg}$ ) of the de-icing nozzle being handled, fatigue (Torres et al., [96]) and others. A de-icing ground crew sprays these liquids and inspects critical surfaces to ensure that no ice remains (Ayache et al., [19]). De-icing operations on the ground must be conducted as quickly as possible not to cause undue delays in flight schedules.

The protection of aircraft against frost build-up is often divided into two aspects, namely ground and in-flight. However, in accidents or incidents due to frost build-up, very often both aspects are involved to varying degrees. For example, in the case of the crash of a Cessna 208B Caravan on Pelée Island in Ontario in January 2004, ice began to build up on the wings while the plane was on the ground and the process continued in flight (Transportation Safety Board of Canada [20]). From 2006 to 2010, the National Safety Board (NSTSB) has documented 228 accidents associated with ice formation in the USA (Appiah-Kubi et al. [21]). These accidents include all those caused by ice in the broad sense, be it frost build-up on aircraft surfaces or ice in engines under certain weather conditions, in flight or on the ground.

Frost formation occurs on aircraft on the ground when the temperature is near or below the freezing point of water. Frost may build up even when ground conditions are not 'frosty', since aircraft surfaces may become very cold during a long flight at high altitude and remain so for considerable time because of thermal inertia, thereby causing ground-level atmospheric moisture to condense (Transport Canada, 2004 [22]). Frost build-up may occur in flight during the summer as well, when the aircraft encounters a thunderstorm cell (Honomichl et al. [23]).

\section{METHODOLOGY}

This critical review of literature of interdisciplinary writings was conducted in two phases:

1. A search from an industrial engineering and human factors engineering perspective. The databases consulted were PubMed/Medline, Compendex/Engineering Village, and Web of Science. The keywords used were (in French and English) occupational health and safety, ergonomics, human factors, integrated risk management, lean, Toyota, Honda, Volvo, Volkswagen, autonomous work, production planning, continuous improvement;

2. A search from an on-ground de-icing and human factors engineering perspective. The databases consulted were Scopus, Compendex/Engineering Village, and Web of Science. The keywords used were (in French and English) aircraft ground deicing, aircraft icing, human factors, human engineering, aircraft icing accident, Canada, aircraft icing statistic, aircraft maintenance, human error; 
For both searches, only documents available in the public domain, published in peer-reviewed journals or as peer-reviewed conference proceedings were retained. The timeframe was 2009 to 2014. Titles and abstracts of papers found in the databases were screened according to their relevance to the subject. Full papers were then read and quality assessed according to classical epistemology rules. Only relevant and high-quality papers were retained for critical analysis. By the snowball effect, flagship studies published prior to the targeted years were also identified.

\section{RESULTS}

\subsection{Integrated risk management, a promising avenue}

Many researchers, research organizations, practitioners and regulatory agencies consider integrating interventions in occupational health and safety with normal business processes to be a very promising focus for scientific advancement in the field of sustainable development. Contributions to development and exchange of knowledge in this sector have evolved from demonstrations of its relevance in the 1990s to more recent proposals and evaluations of models of integration. An integrated approach to occupational health and safety improves working conditions, the surrounding social climate and organizational processes notably by:

1. Improving the corporate brand image and hence labor recruitment, loyalty and satisfaction, improving system quality, reliability, availability and maintainability, increasing productivity and innovation, yielding better organizational decisions;

2. Decreasing direct costs, overhead, redesign, personnel turnover, absenteeism, slacking, inefficiencies, errors and system failures.

Integrated risk management focuses on complex sociotechnical systems involving numerous interdependent risks of diverse nature associated with a diversity of disciplines and in which uncertainty and the expectations of several parties must be taken into consideration. Its ultimate aim is to rank risks in terms of the various issues and constraints in play, and to guide choices among the various means available for managing these risks (avoidance, mitigation, deflection, contingence, retention) (Aubert \& Bernard, 2004).

To achieve this, we need: (1) to understand and formalize the functioning and dysfunction of the system under study; (2) to model the system; (3) to quantify/qualify the model; (4) to apply the model in the field and validate its results. The principal scientific challenge consists of integrating risks characterized at different levels of sophistication (Aubert and Bernard [24]), for example risks for which it is not possible to identify the events that could result (level 0), risks for which there are definable event scenarios (level 4) and finally risks for which the uncertainty can be estimated in quantitative terms (level 6). It is also necessary to materialize this integration in interdisciplinary or even inter-sectorial contexts, which poses the challenge of determining the applicability of definitions and evaluation methods to the uncertainty concept (Péry et al. [25]). The degree of integration of risks will also depend on the size, structure and competitive positioning of the business concerned (Gangolells et al. [26]). Characteristics such as these dictate which management tool to adopt (Rocha [27]).

We note at this point that in conventional management systems, integration of risk is achieved through the application of standardization frameworks on a voluntary basis (Fernandez-Muniz et al. [28]). American Society for Testing and Materials International, (ASTM E2350-07 [29]), Occupational Health and Safety Assessment Series, (OHSAS 
18001-2007), American National Standards Institute/American Industrial Hygiene Association, (ANSI/AIHA Z10-2005), Canadian Standards Association (CSA Z1004-12), British Standards (BS 8800:1996) or British Standards European Norm International Organization for Standardization (BS EN ISO 14001) are the standards most widely applied to occupational health and safety. Adoption of occupational health and safety certification supports the process of getting workers involved in prevention, can lead to improvements or innovations going beyond legal or regulatory requirements and facilitates transparency of business audits and contractual decisions/relations (Kristensen [14]) but does not support the advanced practices of organizational learning (Granerud and Rocha [30]). Standards dealing with management of quality, the environment and occupational health and safety are all based on the Deming wheel. Their integration can lead to overlapping of tasks involving different human resources, and hence challenges of coordination and alignment with business strategy and the potential for financial and social gains (Santos et al. [31]; Zeng et al. [32]). Initial set-up costs are high and the continuous updating of all the documentation can be tedious (Santos et al. [31], Zeng et al. [32]). However, if integration is successful, internal audits become unified, external audits are simplified, employees are better trained, responsibilities are better defined, documentation is clearer, communications are improved, and the entire management system is more effective and efficient, including supply management (Rebelo et al. [33], Oliveira [34], Santos et al. [31]). For project-type processes involving much technical variability, subsystems, temporary locations (e.g. construction, mining, maintenance activities) integration is difficult (Gangolells et al. [26]). The challenges stem from deficiencies in understanding how to integrate these standards at the planning stage and in understanding of risk identification, evaluation and control, and from gaps in support from certification agencies and poor suitability of the technical guides they offer (Gangollels et al. [26]). Some are attempting to meet these challenges for conventional processes in the manufacturing sector (Rebelo et al. [33], Oliveira [34]). Solutions have been explored in the construction and mining sectors (Badri et al. [35], Badri et al. [36, 37], Badri et al. [38]).

Integrated risk management may also be achieved through non-certified management systems, in particular those based on a philosophy of continuous improvement of quality and productivity, such as the so-called Total Quality Management (TQM), lean, six sigma, lean sigma or fit sigma production systems (Yang \& Yang, [97]). Studies examining the occupational health and safety impact of systems called 'lean' indicate positive effects such as increased involvement of workers in control over tasks, greater focus on quality and improved training, task diversification, more teamwork with greater autonomy, a system that treats workers as equals, but also negative effects such as more tasks and stress, less autonomy, more intense and complex work, more intrusive supervision and frequent overtime on short notice (Westgaard and Winkel [16], Dul and Neumann [39], Saurin and Ferreira [40]). These contrasts stem from organizational culture issues, from the maturity of the production philosophy being introduced, from the socioeconomic context of the business and from the level of worker participation (Saurin and Ferreira [40]). We note that the literature provides little support for the tools of such philosophies and their level of maturity, making the scientific implications of the studies difficult to describe and practically impossible to extrapolate to other contexts.

Techniques such as functional analysis, failure mode effects analysis (FMEA), hazard and operability studies (HAZOP), cause/failure trees, the bow-tie model, human error analysis, or other risk analysis techniques (Zahra, J.T. et al. [41], Tixier et al. [42]) in laboratory experiments (Dempsey et al. [43]) or using digital human modeling (Illmann et al. [44], Demirel and Duffy [3], Fritzsche et al. [45], Neumann and Medbo [46], Cimino et al. [47]) have been 
used to complete the comprehension, formalizing and modeling of the decisional subsystem of the system under study. Quantitative or qualitative characterization of such a model can be achieved using Bayesian methods (Knegtering and Pasman [48], Hu et al. [49]) or multi-criteria methods such as AHP (analytical hierarchy process) (Saaty, [98]) or ELECTRE, when specific events can be associated with risks and probabilities of their occurrence can be estimated. When probabilities of occurrence cannot be estimated, consideration must be given to using combinatory or continuous optimization algorithms, depending on the nature of the system under study. Combinatory optimization can be achieved using exact methods (e.g. Markov chains) or approximate methods such as meta-heuristics or techniques of artificial intelligence (Hu et al. [49]). In all cases, the qualitative characterization of a model will necessarily involve elicitation of experts (Knegtering and Pasman [48], Zahra et al. [41]). The advantage of using a decision aid is to be able to use a model repeatedly to make decisions, choose options or set diagnostics where consequences are major and possibly spread out over time and past experience is of little help, all while minimizing the introduction of bias. These are simplified representations of reality, allowing decision-making of which the quality (level of performance of the resulting actions) depends on the model chosen. A decisional process must be in place to guide any decision aid that might be used. The literature identifies explicitly the category of personnel for whom the decisional processes are intended. The question of the resources at their disposition (time, information, finances) and the constraints under which the decisions must be made nevertheless remains crucial.

At the operational level, integrating occupational health and safety into the design and management of a production system means, among other things, integration of these risks into the techniques and tools used to determine production system capacity, to study and measure work, factory layout, stock management, production planning, raw material needs, scheduling, quality management, equipment and facility management and supply management. A few of the avenues that have been explored in published studies are listed in Table 1. Research in this field nevertheless remains emergent and faces the challenges of quantifying empirical relationships, integrating them into mathematical models currently used in operations/industrial engineering management and demonstrating to practitioners the usefulness of these new integrated models (Neumann and Dul [50]). This involves demonstrating their robustness in the face of uncertainty and under the changing conditions of business. The research must also provide assurance that these tools all can be fit harmoniously into a system of strategic management (Asif et al. [51]).

\subsection{Human factors engineering of airliner maintenance and de-icing}

The scientific literature on ergonomics and human factors engineering in aviation has been growing significantly since the Second World War. Questions regarding sustainable human factors engineering in this sector nevertheless remain to be examined (Haslam and Waterson [2]). Among these questions, some are directly related to maintenance workers: Is the green and safe label valid for aircraft in view of the accident and illness statistics indicating that aircraft maintenance is a high-risk occupation? What occupational health and safety risks associated with airliner maintenance work have the greatest influence on the operational performance of airlines? How can these considerations and risks be integrated into the lifecycle of an aircraft? Is the 'Design for Maintainability' approach sufficient? Or is an entirely new systemic engineering model needed? These questions are of crucial importance in the aviation sector, in view of the considerable impact of maintenance worker health and safety on the safety of passengers and the public (Vogt et al. [9]). 


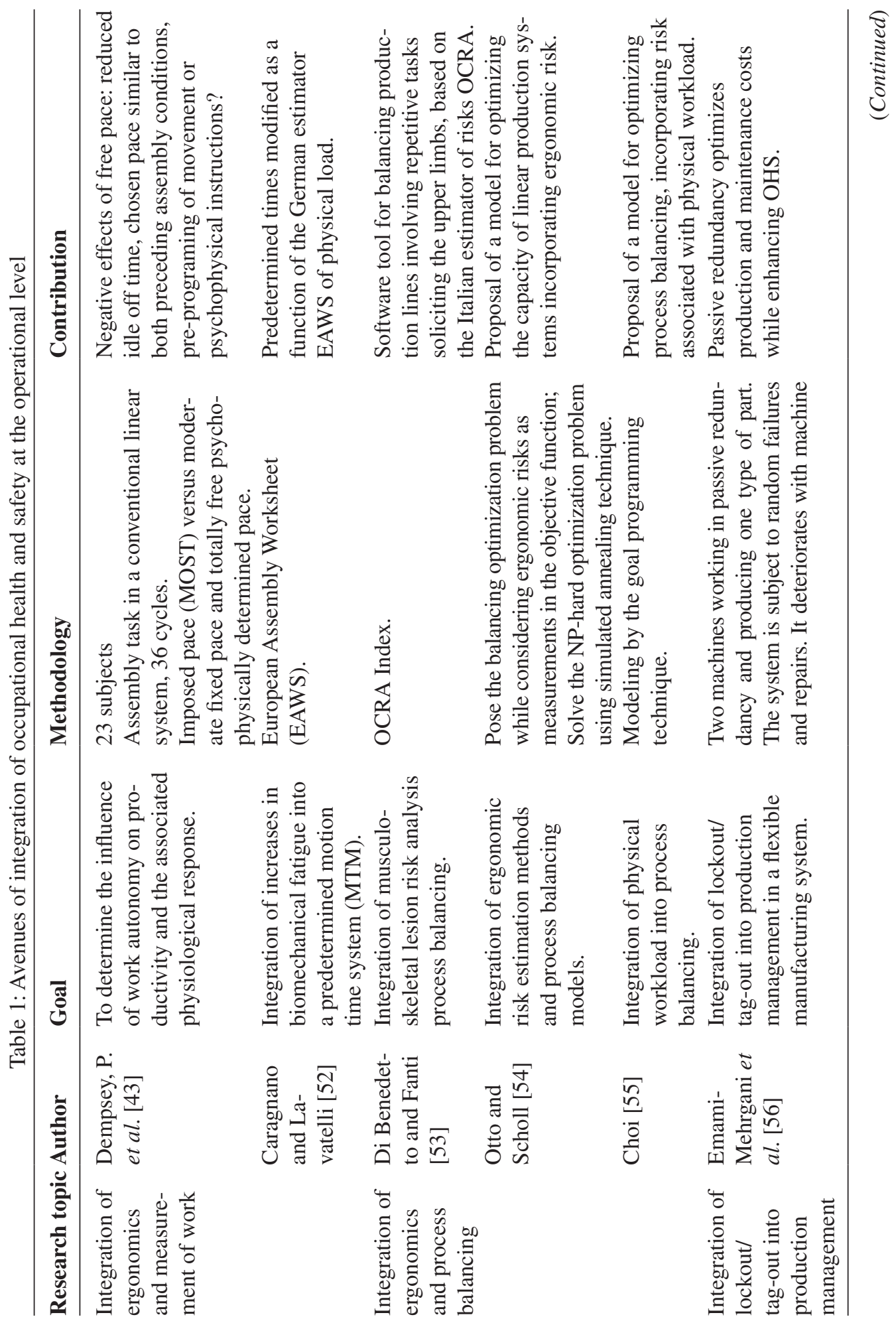




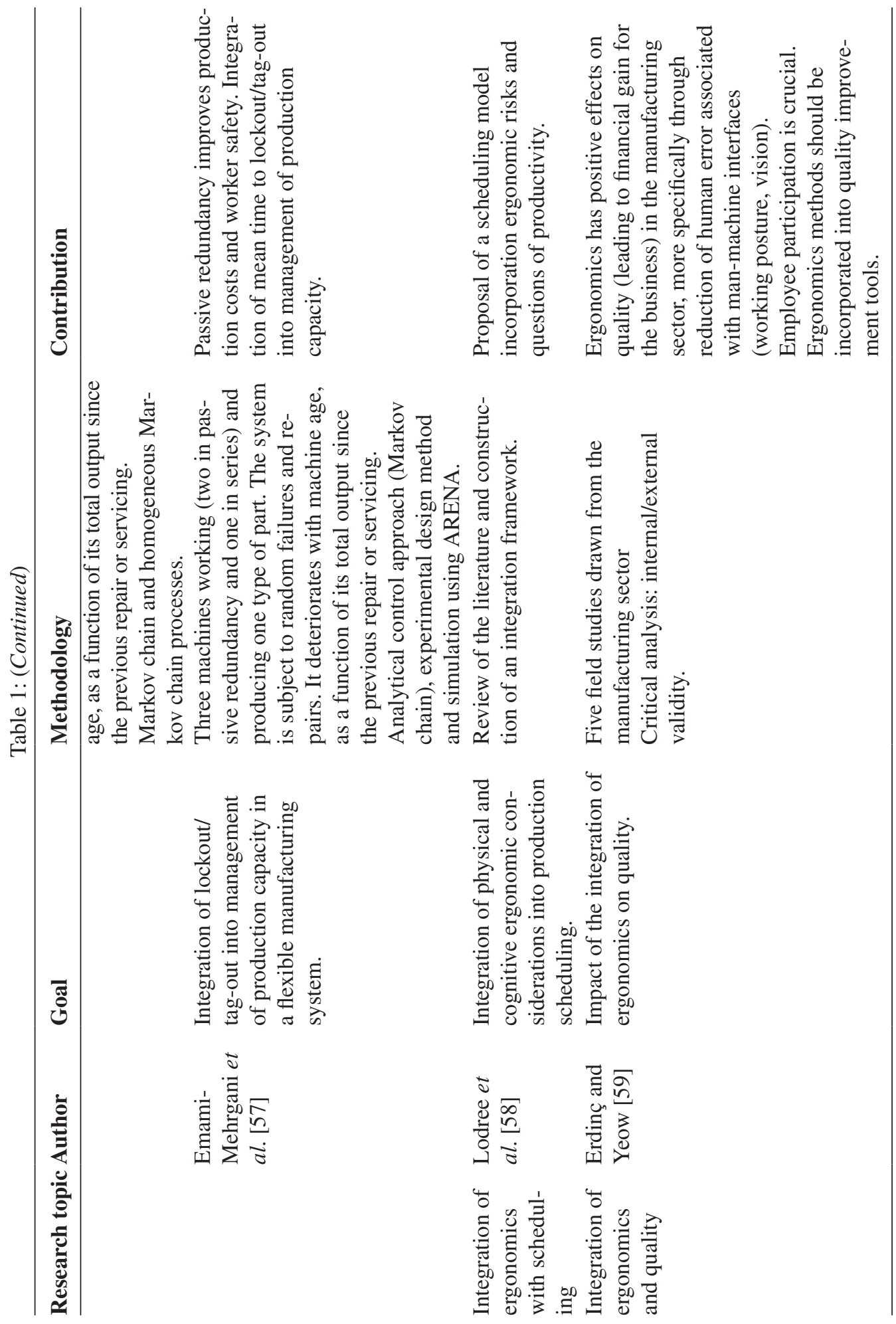


Maintenance activities in the conventional sense are carried out in a wide variety of industrial sectors and workplaces, which implies a wide variety of risks: physical, chemical, biological, ergonomic, machine safety and psychosocial. The activities are not routine in nature and take place in changing work environments (EU-OSHA [60]). Maintenance workers operate under highly restrictive time constraints and communication between the actors involved or affected by their work is often deficient (EU-OSHA [61]). This combination of risks and time constraints may lead to circumvention or deactivation of machine safety devices and hence increased accident rates among maintenance workers (Papadopoulos et al. [62], Reason 2016). These time constraints and communication deficiencies are respectively the second and third causes of incidents in airliner maintenance (Warren et al. [63], Suzuki et al. [64]). Distribution of maintenance tasks is increasing rapidly in many industrial sectors (EU-OSHA [12]) and aviation is certainly no exception. According to the FAA, 64\% of aircraft maintenance activities were distributed in 2007 (McFadden and Worrells [11]). Subcontracting (and sometimes offshoring) these activities may lead to challenges associated particularly with lack of knowledge about the environment and the risks present, increased complexity of work organization (coordination and supervision of fragmented tasks, among others), definition of roles and responsibilities of the various actors involved, and with implementation of occupational health and safety measures, to name only a few (EU-OSHA [60, 61], Papadopoulos et al. [62], Hampson et al., 2012 [88], Quinlan et al., 2013 [91], Gregson et al., 2015 [89]).

Aicraft de-icing activities exist potentially at all the airports of the world where below freezing temperature are likely to occur. According to a study of the United States Environmental Protection Agency (EPA, 2000), around 200 airports in United States performed de-icing operation typically from October through May. In the case of Montréal, Canada, the season extends mainly from November through March. Since aircraft de-icing is a seasonal maintenance activity, the workers are often temporary employees on call. There is much occupational health and safety literature showing an association between job insecurity and increases in work-related accidents (for example Benavides et al. [65], Papadopoulos et al. [62]). The mechanisms explaining this are still being studied. Two factors, namely poor work conditions and lack of experience in and knowledge about the work environment (Benavides et al. [65]), could be significant for de-icing personnel. Fatigue also plays a frequent role in incidents associated with aircraft maintenance. Adequacy of rest, work proficiency, communication and coordination, and work shift are the major factors determining the fatigue of individuals (Wang \& Chuang [66]). Communication in particular appears as important as time constraints in de-icing operations on the ground (Von Thaden [67]). Although now more than 15 years old, the Von Thaden study sums up very well the various human factors that make de-icing on the ground difficult. It emphasizes the impossibility for the pilot without help from inspectors outside to be certain that no ice has accumulated on the aircraft prior to takeoff and still respect the time constraints imposed by the airport.

In the world of aviation, the problem of human-factor-associated variability is often solved by introduction of technology (Vogt et al. [9]), imposing written procedures and documented work codes or training (Cromie et al. [68]). Several regulatory organizations including the ICAO and IHST are nevertheless promoting proactive safe design (Rashid and Braithwaite [8]). We therefore propose that to be sustainable and balance performance criteria with worker wellbeing, the airliner maintenance sector and in particular de-icing operations should aim for systemic design throughout their activity lifecycles. 


\section{DISCUSSION}

5.1 Introduction of technology to reduce human-factor-associated variability in aircraft de-icing

The use of decision-aid tools is one approach studied to help humans make decisions under time pressure. The majority of modern aircraft are equipped with detectors that warn the flight crew that external conditions allow ice formation and in some aircraft activate anti-frost protective systems automatically (Federal Aviation Administration, [69]). These detectors only signal the presence of the conditions and do not propose action. Decision support systems (DSS) have been developed and tested by pilots in flight simulators to determine whether or not they bring any significant benefit. One so-called 'smart' system detects frost build-up in flight by monitoring changes in aircraft aerodynamic performance (Si-Bin et al. [70]). It has been shown that when the information obtained from a DSS is accurate, pilots' management of ice formation is improved, but when the information is inaccurate, their management is poorer than it is without the DSS (Sarter and Schroeder, [71]). As an alternative to this reactive type of decision aid, proactive decision-aid systems could be developed. Instead of waiting for ice to accumulate on the aircraft, the danger of this occurrence could be predicted in advance, based on aircraft flight and atmospheric conditions (Zeppetelli and Habashi, [72]). Most of the research effort has been devoted to aiding pilots, with little attention to decision aids for de-icing personnel on the ground, who in fact can only advise pilots. The most promising systems for ground-level detection of ice formation on wings use cameras and image processing. The current versions detect ice reliably but too slowly for use in airports (Terrace et al. [73]).

5.2 Implementation and documentation of procedures designed to reduce human-factorassociated variability in aircraft de-icing

Studies have focused on delays caused by de-icing operations. Various strategies that take into consideration interactions between airports and airlines have been proposed, including at the de-icing station design stage, to shorten the line-up of aircraft at airports that have multiple de-icing bays (Wu et al. [74, 75]). Reduced line-ups would be beneficial if they allowed reductions in the time constraints imposed on de-icing ground crews.

\subsection{Development of training to reduce human-factor-associated variability in aircraft de-icing}

Various types of training have been devised to reduce the risk associated with frost both in flight and on the ground. For example, pilots practice in flight simulators the actions to undertake to escape from stalling caused by ice. The principal difficulty associated with this approach has been the design of a calculation algorithm that allows the simulator to reproduce realistic behavior of the aircraft (Crider [76]). This is a daunting challenge, since the behavior of a stalling aircraft is difficult to predict and training on a simulator that behaves unrealistically could worsen decision-making in real situations. Meanwhile, de-icing ground workers receive training prior to each de-icing season. The service provider is responsible for this training, but it remains the duty of the air carriers, the certificate holder, to ensure that the service provider knows their approved de-icing procedure. The certificate holder must 
provide a manual with the procedures for each type of aircraft operated (FAA, [93]). Observations on the field are presently in progress to look at the tasks of de-icing ground workers and identify the gap in the training. These observations will lead to training improvements by enabling additional task-oriented formation content.

\subsection{Sustainable, holistic and integrated risk management in aircraft de-icing}

Although human error plays a major role in accidents and incidents associated with aircraft maintenance, various situations are the root cause of such errors: workers inadequately qualified, poor inspections, incorrect replacement of components, erroneous entries in the logbook, and over-extended task distribution (Geibel et al. [77]). Application of the Human Factors Analysis and Classification System (HFACS) to the study of accidents allows consideration of specificities of flight crews, the environment, supervision and organizational factors (Shappell et al. [78]). The AHP can be used to create a weighted model of human factor involvement in aeronautical accidents associated with frost build-up. The AHP requires the creation of a judgment matrix and allows consideration of the interactions between human factors, equipment, management and the environment, which has revealed that human factors and the environment are the dominant factors in accidents associated with frost build-up (Lijuan \& Shinan, [79]).

From human factors research, the trend in aviation has evolved towards the development of tools for anticipating the risks stemming from human error during the performance of critical tasks (Kunlun et al. [80]). One of the difficulties here is that the system variables, in particular the environment and the conditions of use, evolve over time, introducing variability into the probability of accidents. One method proposed for taking this variability into consideration allows identification of critical events that mark the boundary between safety and risk of accident (Luo and $\mathrm{Hu}$ [80]). However, this does not address the essential step of identifying the root cause of human error (Rashid and Braithwaite [81]), which in the case of maintenance, repair and overhaul organizations, may occur in design practices, during manufacturing processes, or at later stages due to organizational, individual or workplace conditions (Rashid et al. [82]).

However, 'In the tradition of product ergonomics, user involvement is considered essential for the development of user-friendly products and services, and the participatory design methods and tools that have been developed in ergonomics could be useful for linking ergonomics to product innovation' (Dul and Neumann [39]). There is now general agreement that products incorporating occupational health and safety concerns will have a positive impact on cost reduction (Rose et al. [83]).

Integration of occupational health and safety concerns could be achieved through the development of wing profiles that are less sensitive to frost build-up, thus reducing the deterioration of aircraft performance (Ghisu et al. [84]) and making de-icing less critical. However, integration of these more robust wing profiles into initial aircraft design is a slow process, if it is occurring at all. For the existing fleet however, only specific training or technological decision aid for de-icing personnel could enable integration of occupational health and safety concerns. For example, the wing of the Cessna 208B Caravan is notoriously sensitive to frost build-up and this aircraft has been involved in numerous accidents due to frost and ice (FSF Editorial Staff [85]). The solution proposed to allow this aircraft to continue to receive clearance to fly under frosting conditions has been primarily to improve pilot training 
(Turner [86]). This measure has proven to be only somewhat effective, since accidents continue to occur (Transportation Safety Board of Canada [87]).

A systemic and integrated design of de-icing operations (Asif et al. [51]) throughout the lifecycle starting at aircraft and anti-icing system design and continuing all the way to elimination of frost, ice or snow on aircraft surfaces is necessary. Such an integrated design does not exist yet and further researches are needed to find appropriate solutions for the aircraft manufacturers, the aircraft carriers and service provider. Decision tools that enable integration of both quantitative and qualitative measurements must be developed. These decision tools should take into account variability for anticipating the risk of accidents. For example, it could be interesting to know how a wing design could impact aircraft ground de-icing activities.

\section{CONCLUSION}

From a sustainable development perspective, proactive support for occupational health and safety throughout human activity lifecycles is essential. Airliner maintenance is a high-risk sector. In the current context of worldwide increases in air traffic, in view of the economic and safety issues stemming from maintenance, balancing of the imperatives of business performance and occupational health and safety can no longer be put off.

Integrated management of business risks and occupational health and safety is a promising avenue. The scientific literature proposes developments as much in the macro realm of business (conventional or non-certified systems management, decisional subsystems) as in the micro realm (operational systems). Airliner maintenance activities and de-icing in particular are fraught with risk, variability and uncertainties and are subject to exacting time constraints. They involve numerous actors and are subject to distribution of tasks.

The aviation industry has attempted to solve the problem of human-factor-associated variability by introducing technology (e.g. decision aids. frost-detecting cameras), imposition of procedures (e.g. to manage line-ups at de-icing stations) and documented work codes, and by training. Modeling and resolution of accidents/incidents via the control of human error run into numerous limitations recognized in the literature, particularly in the case of complex systems such as aircraft de-icing. Integration of occupational health and safety, as an important strategic tool in the business processes of airliner maintenance companies and their quest for better control over business risks, can be achieved only through sustainable, holistic and integrated design of airliner maintenance systems (de-icing activities in the present specific case).

\section{ACKNOWLEDGMENTS}

The authors thank Natural Sciences and Engineering Research Council of Canada (NSERC), the Ministère de l'Économie, de la Science et de l'innovation - Québec (MDEIE), École de technologie supérieure (ÉTS), Fonds de recherche Santé - Québec (FRQS), Fonds de recherche Nature et technologies - Québec (FRQNT) and Fonds de recherche Société et culture - Québec (FRQSC) for financial contributions and support for the development of our interdisciplinary and inter-sector research programs through their research network program.

\section{REFERENCES}

[1] Hinze, J., Godfrey, R. \& Sullivan, J., Integration of construction worker safety and health in assessment of sustainable construction. Journal of Construction and Engineering and Management, 6(139), pp. 594-600, 2013. https://doi.org/10.1061/(asce)co.1943-7862.0000651 
[2] Haslam, R. \& Waterson, P., Ergonomics and sustainability. Ergonomics, 3(56), pp. 343-347, 2013. https://doi.org/10.1080/00140139.2013.786555

[3] Demirel, H.O. \& Duffy, V.G., A sustainable human centered design framework based on human factors. In Duffy, V.G. DHM/HCII Part 1. Springer-Verlag, pp. 307-315, 2013.

[4] Lozano, R. \& Huisingh, D., Inter-linking issues and dimensions in sustainability reporting. Journal of Cleaner Production, 2-3(19), pp. 99-107, 2011.

https://doi.org/10.1016/j.jclepro.2010.01.004

[5] Dul, J., Bruder, R., Buckle, P., Carayon, P., Falzon, P., Marras, W.S., Wilson, J.R. \& van der Doelen, B., A strategy for human factors/ergonomics: developing the discipline and profession. Ergonomics, 55(4), pp. 377-395, 2012.

https://doi.org/10.1080/00140139.2012.661087

[6] OACI (Organisation de l'Aviation Civile Internationale. L'OACI prévoit que le trafic continuera d'augmenter jusqu'à, 2015. available at: http://www.icao.int/Newsroom/ Pages/FR/ICAO-predicts-continued-traffic-growth-through-2015_FR.aspx. (Accessed on: 18 April, 2014).

[7] Boeing. Long-term market. Current market outlook 2013-2032, available at: http:// www.boeing.com/boeing/commercial/cmo/. (accessed 2014.)

[8] Vogt, J., Leonhardt, J., Köper, B. \& Penning, S., Human factors in safety and business management. Ergonomics, 2(53), pp. 149-163, 2010.

https://doi.org/10.1080/00140130903248801

[9] Drury, C.G. \& Johnson, W.B., Writing aviation maintenance procedures that people can/will follow. Proceedings Human Factors and Ergonomics Society 57th Annual Meeting, 57, pp. 997-1001, 2013.

https://doi.org/10.1177/1541931213571223

[10] McFadden, M. \& Worrells, D.S., Global outsourcing of aircraft maintenance. Journal of Aviation Technology and Engineering, 2(1), pp. 63-73, 2012.

https://doi.org/10.5703/1288284314659

[11] EU-OSHA, 2010. Factsheet 90 - Maintenance and OSH - A Statistical Picture. Office for Official Publications of the European Communities, Luxembourg, available at: http://osha.europa.eu/en/publications/factsheets/en.90.pdf/view

[12] HESAPRO, The link between productivity and health and safety at work. Background research paper, April, 32 pages, 2013.

[13] Kristensen, P.S., Managing OHS: A route to a new negotiating order in high-performance work organisations? Safety Science, 7(49), pp. 964-973, 2011.

https://doi.org/10.1016/j.ssci.2011.02.001

[14] Costella, M.F., Saurin, T.A. \& De Macedo Guimaraes, L.B., A method for assessing health and safety management systems from resilience engineering perspective. Safety Science, 8(47), pp. 1056-1067, 2009.

https://doi.org/10.1016/j.ssci.2008.11.006

[15] Westgaard, R.H. \& Winkel, J., Occupational musculoskeletal and mental health: significance of rationalization and opportunities to create sustainable production systems a systematic review. Applied Ergonomics, 2(42), pp. 261-296, 2011. https://doi.org/10.1016/j.apergo.2010.07.002

[16] Brown, A.P., Aircraft performance degradation - the effects of inflight icing upon lift, drag and propulsive efficiency. SAE Technical Paper 2011-38-0073, 2011. 
[17] Hannat, R. \& Morency, F., Numerical validation of conjugate heat transfer method for anti-/de-icing piccolo system. Journal of Aircraft, 1(51), pp. 104-116, 2014. https://doi.org/10.2514/1.c032078

[18] Ayache, A., Morency, F. \& Nadeau, S., Évaluation de la fatigue dans l'activité de dégivrage d'avions au sol et ses effets sur la performance. Canadian Aeronautics and Space Institute 60th Aeronautics Conference AERO 2013, Toronto, Ontario, Canada, April 30, 2013.

[19] Transportation Safety Board of Canada 2006. Aviation investigation report. Loss of Control, Georgian Express Ltd. Cessna 208B Caravan C-FAGA Pelee Island, Ontario January 17, 2004.

[20] Appiah-Kubi, P., Martos, B., Atuahene, I. \& William, S., U.S. inflight icing accidents and incidents. IIE Annual Conference and Expo 2013. 2006 to 2010, 2013.

[21] Transport Canada. When in Doubt... Small and Large Aircraft. Aircraft Critical Surface Contamination Training For Aircrew and Groundcrew, report number TP 10643E, Ottawa, Chapter 2, 2014.

[22] Honomichl, S.B., Detwiler, A.G. \& Smith, P.L., Observed hazards to aircraft in deep summertime convective clouds from 4-7 km. Journal of Aircraft, 50(3), pp. 926-935, 2013. https://doi.org/10.2514/1.c032057

[23] Aubert, B. \& Bernard, J.G., Mesure intégrée du risque dans les organisations, Presses de l'Université de Montréal, 524 pages, 2004.

[24] Péry, A.R.R., Schüürmann, G., Ciffroy, P., Faust, M., Backhaus, T., Aicher L., Mombelli, E., Teddy, C., Cronin, M.T.D., Tissot, S., Andres, S., Bringnon, J.M., Frewer, L., Georgiou, S., Mattas, K., Vergnaud, J.C., Peijnenburg, W., Capri, E., Marchis, A. \& Wilks, M.F., Perspectives for integrating human and environmental risk assessment and synergies with socio-economic analysis. Science of the Total Environment, 456-457, pp. 307-316, 2013.

https://doi.org/10.1016/j.scitotenv.2013.03.099

[25] Gangollels, M., Casals, M., Forcada, N., Fuertes, A. \& Roca, X., Model for enhancing integrated identification, assessment, and operational control of on-site environmental impacts and health and safety risks in construction firms. Journal of Construction Engineering and Management, 2(139), pp. 138-147, 2013.

https://doi.org/10.1061/(asce)co.1943-7862.0000579

[26] Rocha, R.S., Institutional effects on occupational health and safety management systems. Human Factors and Ergonomics in Manufacturing \& Services Industries, 3(20), pp. 211-225, 2010.

https://doi.org/10.1002/hfm.20176

[27] Fernandez-Muniz, B., Montes-Péon, J.M. \& Vasquez-Ordas, C.J., Occupation risk management under the OHSAS 18001 standard: analysis of perceptions and attitudes of certified firms. Journal of Cleaner Production, 24, pp. 36-47, 2012. https://doi.org/10.1016/j.jclepro.2011.11.008

[28] ASTM, Standard Guide for Integration of Ergonomics/Human Factors into New Occupational Systems. E235007, 10 pages, 2013.

[29] Granerud, L. \& Rocha, R., Organisational learning and continuous improvement of health and safety in certified manufacturers. Safety Science, 7(49), pp. 1030-1039, 2011. https://doi.org/10.1016/j.ssci.2011.01.009 
[30] Santos, G., Mendes, F. \& Barbosa, J., Certification and integration of management systems: the experience of Portuguese small and medium enterprises. Journal of Cleaner Production, 17-18(19), pp. 1965-1974, 2011. https://doi.org/10.1016/j.jclepro.2011.06.017

[31] Zeng, S.X., Tam, C.M. \& Tam, V.W.Y., Integrating safety, environmental and quality risks for project management using a FMEA method. Economics of Engineering Decisions, 21(1), pp. 44-52, 2010.

[32] Rebelo, M.F., Santos, G. \& Silva, R., A generic model for integration of quality, environment and safety management systems. The TQM Journal, 26(2), pp. 143-159, 2014. https://doi.org/10.1108/tqm-08-2012-0055

[33] De Oliveira, O.J., Guidelines for the integration of certifiable management systems in industrial companies. Journal of Cleaner Production, 57, pp. 124-133, 2013. https://doi.org/10.1016/j.jclepro.2013.06.037

[34] Badri, A., Nadeau, S. \& Gbodossou, A., A new practical approach to risk management for underground mining project in Quebec. Journal of Loss Prevention in the Process Industries, 26(6), pp. 1145-1158, 2013. https://doi.org/10.1016/j.jlp.2013.04.014

[35] Badri, A., Nadeau, S. \& Gbodossou, A., Occupational health and safety risks: towards the integration into project management. Safety Science, 50(2), pp. 190-198, 2012. https://doi.org/10.1016/j.ssci.2011.08.008

[36] Badri, A., Nadeau, S. \& Gbodossou, A., Proposal of a risk-based analytical approach for integrating occupational health and safety into project risk evaluation. Accident Analysis and Prevention, 48, pp. 223-234, 2012. https://doi.org/10.1016/j.aap.2011.05.009

[37] Badri, A., Nadeau, S. \& Gbodossou, A., Integration of OHS into risk management in an open-pit mining project in Quebec (Canada). Minerals, 1(1), pp. 3-29, 2011. https://doi.org/10.3390/min1010003

[38] Dul, J. \& Neumann, P., Ergonomics contributions to company strategies. Applied Ergonomics, 40(4), pp. 745-752, 2009. https://doi.org/10.1016/j.apergo.2008.07.001

[39] Saurin, T.A. \& Ferreira, C.F., The impacts of lean production on working conditions: a case study of a harvester assembly line in Brazil. International Journal of Industrial Ergonomics, 39(2), pp. 403-412, 2009. https://doi.org/10.1016/j.ergon.2008.08.003

[40] Zahra, J.T., Seyyed, S.H. \& Aziruddin, R., Risk assessment of ergonomic risk factors at construction sites. Applied Mechanics and Materials, 330, pp. 857-861, 2013. https://doi.org/10.4028/www.scientific.net/amm.330.857

[41] Tixier, J., Dusserre, G., Salvi, O. \& Gaston, D., Review of 62 risk analysis methodologies of industrial plants. Journal of Loss Prevention in the Process Industries, 15(4), pp. 291-303, 2002. https://doi.org/10.1016/s0950-4230(02)00008-6

[42] Dempsey, P., Mathiassen, S.E., Jackson, J. \& O’Brien, N., Influence of three principles of pacing on the temporal organisation of work during cyclic assembly and disassembly tasks. Ergonomics, 53(11), pp. 1347-1358, 2010. https://doi.org/10.1080/00140139.2010.520745 
[43] Illmann, B., Fritzsche, L., Leidholdt, W., Bauer, S. \& Dietrich, M., Application and future developments of EMA in digital production planning and ergonomics. In Duffy, V.G., DHM/HCII, Part II, LNCS 8026, pp. 66-75, 2013.

[44] Fritzsche, L., Leidholdt, W., Bauer, S., Jäckel, T. \& Moreno, A., Interactive production planning and ergonomic assessment with digital human models - introducing the editor for manual work activities (ema). Work, 41, pp. 4428-4432, 2012.

[45] Neumann, W.P. \& Medbo, P., Integrating human factors into discrete event simulations of parallel flow strategies. Production Planning \& Control, 20(1), pp. 3-16, 2009. https://doi.org/10.1080/09537280802601444

[46] Cimino, A., Longo, F. \& Mirabelli, G., A Multi-measure-based methodology for the ergonomic effective design of manufacturing system workstations. International Journal of Industrial Ergonomics, 39(2), pp. 447-455, 2009.

https://doi.org/10.1016/j.ergon.2008.12.004

[47] Knegtering, B. \& Pasman, H., The safety barometer. How safe is my plant today? Is instantaneously measuring safety level Utopia or realizable? Journal of Loss Prevention in the Process Industries, 26(4), pp. 821-829, 2013.

https://doi.org/10.1016/j.jlp.2013.02.012

[48] Hu, J., Zhang, L., Ma, L. \& Liang, W., An integrated safety prognosis model for complex system based on dynamic bayesian network and ant colony algorithm. Expert Systems with Applications, 38(3), pp. 1431-1446, 2011. https://doi.org/10.1016/j.eswa.2010.07.050

[49] Neumann, P. \& Dul, J., Human factors: spanning the gap between OM and HRM. International Journal of Operations \& Production Management, 30(9), pp. 923-950, 2010. https://doi.org/10.1108/01443571011075056

[50] Asif, M., de Bruijn, E.J. \& Fisscher, O.A.M., Meta-management of integration of management systems. TQM Journal, 22(6), pp. 570-582, 2009.

https://doi.org/10.1108/17542731011085285

[51] Caragnano, G. \& Lavatelli, I., ERGO-MTM model: an integrated approach to set working times based upon standardized working performance and controlled biomechanical load. Work, 41, pp. 4422-4427, 2012.

[52] Di Benedetto, R. \& Fanti, M., An integrated tool to support engineers for WMSDs risk assessment during the assembly line balancing. Work, 41, pp. 2329-2333, 2012.

[53] Otto, A. \& Scholl, A., Incorporating ergonomic risks into assembly line balancing. European Journal of Operational Research, 212(2), pp. 277-286, 2011. https://doi.org/10.1016/j.ejor.2011.01.056

[54] Choi, G., A goal programming mixed-model line balancing for processing time and physical workload. Computers \& Industrial Engineering, 57(1), pp. 395-400, 2009. https://doi.org/10.1016/j.cie.2009.01.001

[55] Emami-Mehrgani, B., Nadeau, S. \& Kenné, J.P., Lockout/tagout and operational risks in the production control of manufacturing systems with passive redundancy. International Journal of Production Economics, 132(2), pp. 165-173, 2011. https://doi.org/10.1016/j.ijpe.2011.03.028

[56] Emami-Mehrgani, B., Kenné, J.P. \& Nadeau, S., Lockout/tagout and optimal production control policies in failure-prone non-homogeneous transfer lines with passive redundancy. International Journal of Production Research, 51(4), pp. 1006-1023, 2013. https://doi.org/10.1080/00207543.2012.662305 
[57] Lodree E.J. Jr., Geiger, C.D. \& Jiang, X., Taxonomy for integrating scheduling theory and human factors: review and research opportunities. International Journal of Industrial Ergonomics, 39(1), pp. 39-51, 2009.

https://doi.org/10.1016/j.ergon.2008.05.001

[58] Erdinç, O. \& Yeow, P.H.P., Proving external validity of ergonomics and quality relationship through review of real-world case studies. International Journal of Production Research, 49(4), pp. 949-962, 2011.

https://doi.org/10.1080/00207540903555502

[59] EU-OSHA. Factsheet 63 - Procurement of Maintenance Services and Health and Safety at Work: Office for Official Publications of the European Communities, Luxembourg, available at: http://osha.europa.eu/en/publications/factsheets/en.63.pdf/view

[60] EU-OSHA, Factsheet 62 - Safe Maintenance: Working with Contractors and Subcontractors: Office for Official Publications of the European Communities, Luxembourg, 2012. Available at: http://osha.europa.eu/en/publications/factsheets/en.62.pdf/view

[61] Papadopoulos, G., Georgiadou, P., Papazoglou, C. \& Michaliou, K., Occupational and public health and safety in a changing work environment: an integrated approach for risk assessment and prevention. Safety Science, 48(8), pp. 943-949, 2010. https://doi.org/10.1016/j.ssci.2009.11.002

[62] Warren, W.R., Blickensderfer, B., Cruit, J. \& Boquet, A., Shift turnover strategy and time in aviation maintenance. Proceedings Human Factors and Ergonomics Society 57th Annual Meeting, 57(1), pp. 46-50, 2013. https://doi.org/10.1177/1541931213571013

[63] Suzuki, T., von Thaden, T.L. \& Geibel, W.D., Coordination and safety behaviors in commercial aircraft maintenance. Proceedings of the Human Factors and Ergonomics Society 52nd Annual Meeting, 52(1), pp. 89-93, 2008.

https://doi.org/10.1177/154193120805200120

[64] Benavides, F.G., Associations between temporary employment and occupational injury: what are the mechanisms? Occupational Environmental Medicine, 63, pp. 416-421, 2006. https://doi.org/10.1136/oem.2005.022301

[65] Wang, T.C. \& Chuang, L.H., Psychological and physiological fatigue variation and fatigue factors in aircraft line maintenance crews. International Journal of Industrial Ergonomics, 44(1), pp. 107-113, 2014.

https://doi.org/10.1016/j.ergon.2013.11.003

[66] Von Thaden, T.L., Air carrier deicing: human factors approach for building redundancy and commonality in standard operating procedures. Transportation Research Record, 1567, pp. 41-48, 1997.

https://doi.org/10.3141/1567-06

[67] Cromie, S., Liston, P., Ross, D., Corrigan, S., Vani, L., Lynch, D., Demosthenous, S., Leva, C., Kay, A. \& Demosthenous, V., Human and organisational factors training as a risk management strategy in an aviation maintenance company. Chemical Engineering Transactions, 33, pp. 445-450, 2013.

[68] Federal Aviation Administration. Aviation maintenance technician handbookairframe, (1), FAA-H-8083-31, USA, chapter 15, 2012.

[69] Si-Bin, Y., Tong, G. \& Jian-Liang, A., H parameter identification and H2 feedback control synthesizing for inflight aircraft icing. Journal of Shanghai Jiaotong University (Sci.), 3(18), pp. 317-325, 2013.

https://doi.org/10.1007/s12204-013-1401-6 
[70] Sarter, N.B. \& Schroeder, B., Supporting decision-making and action selection under time pressure and uncertainty: The case of in-flight icing. Human Factors, 43(4), pp. 573-583, 2001. https://doi.org/10.1518/001872001775870403

[71] Zeppetelli, D. \& Habashi, W.G., In-flight icing risk management through computational fluid dynamics-icing analysis. Journal of Aircraft, 49(2), pp. 611-621, 2012. https://doi.org/10.2514/1.c031609

[72] Terrace, S.M., Bender, K.D., Sierra, E.A., Marcil, I., D’ Avirro, J., Pugacz, E. \& Eyre, F., Comparison of human ice detection capabilities and ground ice detection system performance under post deicing conditions. Proceedings of the Human Factors and Ergonomics Society, 50(7), pp. 2051-2055, 2006. https://doi.org/10.1177/154193120605001772

[73] Wu, M., Li, L. \& Chen, B., Optimization research of the aircraft deicing problem. Advanced Materials Research, 616-618, pp. 1926-1929, 2013. https://doi.org/10.4028/www.scientific.net/amr.616-618.1926

[74] Wu, M., Chen, B. \& Xing, Z., Analysis of centralized aircraft deicing process. Applied Mechanics and Materials, 101-102, pp. 779-782, 2011. https://doi.org/10.4028/www.scientific.net/amm.101-102.779

[75] Crider, D.A., Upset recovery training: lessons from accidents and incidents. Aeronautical Journal, 1160(114), pp. 629-636, 2010. https://doi.org/10.1017/s0001924000004103

[76] Geibel, W.D., Von Thaden, T.L. \& Suzuki, T., Issues that precipitate errors in airline maintenance. Proceedings of the Human Factors and Ergonomics Society, 52(1), pp. 94-98, 2008. https://doi.org/10.1177/154193120805200121

[77] Shappell, S., Detwiler, C., Holcomb, K., Hackworth, C., Boquet, A. \& Wiegmann, D.A., Human error and commercial aviation accidents: An analysis using the human factors analysis and classification system. Human Factors, 49(2), pp. 227-242, 2007. https://doi.org/10.1518/001872007x312469

[78] Lijuan, C. \& Shinan, C., An approach of AHP for human factors analysis in the aircraft icing accident. Procedia Engineering, 17, pp. 63-69, 2011. https://doi.org/10.1016/j.proeng.2011.10.008

[79] Kunlun, S., Yan, L. \& Ming, X., A safety approach to predict human error in critical flight tasks. Procedia Engineering, 17, pp. 52-62, 2011.

https://doi.org/10.1016/j.proeng.2011.10.007

[80] Luo, P. \& Hu, Y., System risk evolution analysis and risk critical event identification based on event sequence diagram. Reliability Engineering and System Safety, 114, pp. 36-44, 2013. https://doi.org/10.1016/j.ress.2013.01.002

[81] Rashid, H.S.J., Place, C.S. \& Braithwaite, G.R., Eradicating root causes of aviation maintenance errors: Introducing the AMMP. Cognition, Technology and Work, 16(1), pp. 71-90, 2014. https://doi.org/10.1007/s10111-012-0245-4

[82] Rose, L.M., Orrenius, U.E. \& Neumann, W.P., Work environment and the bottom line: survey of tools relating work environment to business results. Human Factors and Ergonomics in Manufacturing \& Service Industries, 23(5), pp. 368-381, 2011. https://doi.org/10.1002/hfm.20324 
[83] Ghisu, T., Jarrett, J.P. \& Parks, G.T., Robust design optimization of airfoils with respect to ice accretion. Journal of Aircraft, 48(1), pp. 287-304, 2011.

https://doi.org/10.2514/1.c031100

[84] FSF Editorial Staff, Investigators urge restrictions on cessna 208 icing operations. Flight Safety Foundation Accident Prevention, 2(63), 2006.

[85] Turner, T.P., Saving The Cessna Caravan. Aviation Safety Magazine. Belvoir Media Group, 2008.

[86] Transportation Safety Board of Canada 2014. Loss of control and collision with terrain gogal air services limited Cessna 208B, C-GAGP Snow Lake, Manitoba, November 18, 2012.

[87] Reason, J., Managing the risks of organizational accidents. Taylor and Francis, UK, 2016.

[88] Hampson, I., Junor, A., \& Gregson, S., Missing in action: aircraft maintenance and the recent 'HRM in the airlines' literature. International Journal of Human Resource Management, 23(12), pp. 2561-2575, 2012.

https://doi.org/10.1080/09585192.2011.633278

[89] Gregson, S., Hampson, I., Junor, A., Fraser, D., Quinlan, M. \& Williamson, A., Supply chains, maintenance and safety in the Australian airline industry, Journal of Industrial Relations, 57(4), pp. 604-623, 2015.

https://10.1177/0022185615582234

[90] Quinlan, M., Hampson, I. \& Gregson, S., Slow to learn: Regulatory oversight of the safety of outsourced aircraft maintenance in the USA. Policy and Practice in Health and Safety, 12(1), pp. 71-90, 2014.

https://doi.org/10.1080/14774003.2014.11667798

[91] Quinlan, M., Hampson, I. \& Gregson, S., Outsourcing and offshoring aircraft maintenance in the US: Implications for safety. Safety Science, 57, pp. 283-292.

https://doi.org/10.1016/j.ssci.2013.02.011

[92] Federal Aviation Administration, Adjustment of Compliance Date for Review of Outsourcing of (Third Party Provider) Aircraft Ground Deicing at Foreign Locations, FAA NOTICE - N 8900.26, available at: https://www.faa.gov/documentLibrary/media/ Notice/n8900_33.pdf. (accessed 2007.)

[93] Federal Aviation Administration, Ground deicing and anti-icing program, Document Information, AC 120-60B, available at: https://www.faa.gov/regulations_policies/advisory_circulars/index.cfm/go/document.information/documentID/23199. (accessed 20 Décember 2004).

[94] European Aviation Safety Agency. Regulation of ground de-icing and anti-icing services in the EASA Member States, Interim Report. EASA.2009.OP 21, available at: https://www.easa.europa.eu/system/files/dfu/EASA.2009_4\%20Interim_Report.pdf (accessed 2009).

[95] United States Environmental Protection Agency, Preliminary Data Summary. Airport Deicing Operations (Revised), EPA-821-R-00-016, available at: https://www.epa.gov/sites/production/ files/2015-06/documents/airport-deicing-pds-2000.pdf. (accessed August 2000).

[96] Torres, Y., Nadeau, S. \& Morency, F., Study of fatigue and workload among aircraft deicing technicians. Occupational Ergonomics, 13(2), pp. 79-90, 2016.

https://doi.org/10.3233/oer-160240

[97] Yang, C.-C \& Yang, K.-J, An integrated model of the toyota production system with total quality management and people factors. Human Factors and Ergonomics in Manufacturing \& Service Industries, 23(5), pp. 450-461, 2013.

https://doi.org/10.1002/hfm.20335 
[98] Saaty, T.L., Relative measurement and its generalization in decision making; why pairwise comparisons are central in mathematics for the measurement of intangible factors. The Analytic Hierarchy/Network Process, Royal Academy of Sciences, Spain, Series A. Mathematics, 102(2), pp. 251-318, 2008.

https://doi.org/10.1007/bf03191825 